\title{
Fundamentos teológico-políticos da Musica Poetica alemã
}

\author{
Cassiano de Almeida Barros
}

\author{
Universidade do Estado de Santa Catarina | Brasil
}

\begin{abstract}
Resumo: Seguindo Bourdieu (2000), assumo que a compreensão das formas simbólicas de representação artística depende da compreensão da "visão do mundo" própria do grupo social ao qual os artistas pertencem e a partir da qual criam suas obras. Essa perspectiva, quando aplicada aos estudos dedicados às poéticas musicais alemãs dos séculos XVI, XVII e XVIII, justifica a necessidade do resgate dos fundamentos teológico-políticos dessa tradição e da elaboração de uma compreensão sobre eles. Além disso, demanda o restabelecimento de homologias estruturais entre eles e os princípios criativos da música, como forma de colocar em evidência a natureza política e religiosa do exercício musical, comprometido com a manutenção da ordem social, a construção do bem comum e o desígnio divino. Para além do compor e executar, esse exercício implicava no compromisso de tornar o discurso musical inteligível para o público e acessível às futuras geraçóes de compositores, como material para imitação.
\end{abstract}

Palavras-chave: Martinho Lutero, Musica Poetica, teologia política, educação luterana, Joachim Burmeister.

\begin{abstract}
Following Bourdieu (2000), I assume that the understanding of the symbolical forms of artistic representation depends on the understanding of the "worldview" of the social group to which the artist belongs and from which he creates his works. This perspective, when applied to the studies dedicated to the German musical poetics of the Sixteenth, Seventeenth and Eighteenth centuries, justifies the recovery of the theological-political fundaments of this tradition and the elaboration of its understanding. Besides that, it demands the reestablishment of the structural homologies between them and the creative principles of the music, evidencing the religious and political nature of the musical act, compromised with the maintenance of the social order, the construction of the common good and God's design. In addition to composing and performing, this act implied a commitment to making musical discourse intelligible to the public and accessible to future generations of composers, as material for imitation.
\end{abstract}

Keywords: Martin Luther, Musica Poetica, political theology, Lutheran education, Joachim Burmeister. 
Musica Poetica constituiu-se no campo de conhecimento da música luterana
seiscentista como o ramo dedicado à sistematização dos processos criativos, que tinham
como fim a conservação de uma certa produção musical escrita, de natureza religiosa, polifônica e modal, composta a partir de modelos específicos autorizados pelas instituiçóes teológico-políticas vigentes. A expressão campo de conhecimento da música toma como referência a ideia de campo de Bourdieu (2003, p. 120-121; 2000, p. 234), que pode ser definida como um espaço social estruturado por leis e regras específicas, que se relaciona com um contexto social mais amplo, e que se constitui como um lugar de tomada de posição dos agentes sociais e instituições que o integram. Esse campo tem o conhecimento da música como seu capital, em relação ao qual esses diversos agentes e instituiçôes assumem suas posições em defesa da conservação ou da ruptura do estado de coisas que esse capital encerra.

No contexto da Musica Poetica alemã, o conhecimento da música é organizado teleologicamente em três categorias, a saber, a especulativa, a prática e a poética, que tomam contornos escolásticos contrafeitos diversamente por músicos protestantes ao longo do século XVI, XVII e XVIII. Ali, esse conhecimento adquire grande valor por sua utilidade na promoção da palavra divina e da fé (LUTERO, 2017a), como se verificará adiante, cobrando seu sentido das homologias entre os campos musical, teológico, político e educacional.

Admito, com Bourdieu (1989), que os diversos campos coexistentes num determinado contexto histórico compartilham de conceitos e modos de pensamento comuns, derivados de propriedades gerais características do próprio contexto que os interliga, e que as relações de permuta linguística entre esses campos devem ser pensadas "como outros tantos mercados que se especificam segundo a estrutura das relaçốes entre os capitais linguísticos ou culturais dos interlocutores ou dos seus grupos” (BOURDIEU, 1989, p. 68-69). Assim, reconheço que a própria (re)construção dos objetos de conhecimento exige e fundamenta a transferência conceitual e terminológica entre campos, conforme as homologias estruturais estabelecidas, eliminando de sua compreensão a ideia descontextualizada da metáfora meramente explicativa.

Nessa mesma perspectiva, Hansen (2019, p. 26) afirma que essas homologias permitem definir uma espécie de forma mentis específica, cujas categorias estruturais, funcionais e valorativas permitem reconstruir o diferencial histórico da representação artística e evidenciar a "radical 
descontinuidade” dela em relação aos programas historiográficos, críticos e artísticos iluministas e pós-iluministas. Com efeito, assevera ainda que "tais programas continuam se apropriando das representaçôes do século XVII, repetindo as categorias da crítica romântica do século XIX como universais transistóricos ou simplesmente afirmando a pós-modernidade da operação" (HANSEN, 2019, p. 26), e se opõe a isso, propondo especificar lógicas discursivas e condicionamentos materiais e institucionais, recuperando os diferenciais históricos de cada representação analisada que possibilitem relativizar e criticar eventuais apropriaçóes anacrônicas.

Com relação a isso, Bourdieu acrescenta:

É preciso pôr cientificamente à prova a "unidade cultural" de uma época e de uma sociedade, que a história da arte e da literatura aceitam como um postulado tácito (...). Tratar-se-ia de examinar, para cada uma das configuraçóes históricas consideradas, de um lado as homologias estruturais entre campos diferentes, que podem ser o princípio de encontros ou de correspondências que não devem nada ao empréstimo, e do outro lado as trocas diretas, que dependem, em sua forma e em sua própria existência, das posições ocupadas, em seus campos respectivos, pelos agentes ou as instituiçôes que lhes dizem respeito, portanto, da estrutura desses campos, e também das posições relativas desses campos na hierarquia que se estabelece entre eles no momento considerado, determinando todas as espécies de efeitos de dominação simbólica. (BOURDIEU, 2000, p. 227)

De acordo com essa perspectiva, a posição hierárquica que cada campo analisado ocupa em relação aos demais determina a ordem simbólica que orienta, no exercício do poder instituído, a conservação ou a ruptura dos modelos e tradiçôes vigentes. Assim, no contexto dessas relaçôes é que se constituem as possibilidades em ato e em potência de tomada de posição dos diferentes artistas, materializadas naquilo que produziram e deixaram de produzir no exercício da concorrência que os opunha e das alianças que estabeleceram entre si. Nesse jogo de forças que se estabeleceu entre os diversos agentes e instituiçóes, prevaleceram os interesses daqueles que detinham o poder, fazendo passar ao ato as possibilidades que lhes pareceram mais conformes às suas intençôes e interesses específicos, configurando assim uma determinada produção musical como efeito da dominação simbólica.

Nesse sentido, reconheço que a compreensão da Musica Poetica seiscentista alemã depende da recuperação das diversas relações entre as ideias oriundas dos campos teológico-político, educacional e artístico do período, assim como outros tantos campos que constituem a visão de mundo com e 
para a qual os compositores produziam suas obras. Neste texto, restrinjo-me ao estudo de alguns fundamentos desses três campos, sem a pretensão de esgotá-los, mas sim com a intenção de fomentar a reflexão sobre esse objeto de estudos, a poética musical luterana no século XVI.

\section{A teologia-política de Martinho Lutero}

Segundo Skinner (2004, p. 3), a base da teologia luterana assenta-se sobre a ideia da natureza indigna do homem. Contrapondo-se à compreensão tomista até então vigente, que postulava a crença na capacidade humana de intuir e seguir as leis de Deus, Lutero defendia uma compreensão agostiniana, pessimista, que enfatizava da natureza humana sua corrupção e imperfeição, determinadas desde a origem adâmica pela queda, e que conduziam o homem naturalmente em direção oposta à salvação.

A correção desse desvio da natureza, conforme aponta McNeil (apud Skinner, 1996, p. 287), não se efetuava pela via racional, pois, para Lutero, a racionalidade humana, justamente por sua qualidade humana, seria incapaz de superar sua origem terrena, imperfeita, enferma e condenada, e alcançar os mistérios da vontade divina, que determinou tudo o que existiu, existe e existiria no mundo. Essa concepção assumia a existência de um Deus oculto [Deus absconditus], conforme relata Skinner (1996, p. 287), que não poderia ser compreendido em absoluto pelos homens, pois Sua vontade seria inescrutável, assim como seria imutável, eterna, onipotente e ordenaria tudo o que acontecia no mundo. Por outro lado, havia uma face de Deus revelada por meio do Verbo, das Escrituras, cuja vontade se tornou então objeto de pregação, revelação, oferta e adoração. Essa compreensão de Deus que distingue Sua face revelada de Sua face oculta constitui a base da doutrina luterana, que postula a dupla natureza de Deus.

Havia ainda um segundo corolário relativo a essa concepção do homem e de Deus, que concluía que o homem jamais poderia praticar algum ato que o justificasse diante de Deus e, assim, contribuísse para salvá-lo, pois todas as ações humanas expressavam única e exclusivamente sua natureza decaída. Nesses termos, considerando a disputa entre Erasmo de Roterdã e Lutero acerca do livre arbítrio, pode-se compreender a ideia de Lutero de que o livre arbítrio dos homens não representaria caminho algum para a salvação, mesmo que esse juízo o levasse à realização de ações 
virtuosas, pois "sendo os homens carne, e somente apreciando a mesma carne, segue-se que a livre escolha resulta apenas no pecado", e que todos os homens estão "marcados para a perdição, por seu desejo ímpio.” (BOISSET, apud SKINNER, 1996, p. 288).

A distância entre a impotência humana, que desencorajava a qualquer um de nutrir a esperança de se salvar mediante seus próprios esforços, e a onipotência divina, que "opera tudo em tudo" a partir de uma completa onisciência do tempo, pode ser superada apenas pela disposição divina em "mostrar misericórdia ante os pecadores, e a justificá-los desse modo, libertando-os de sua injustiça” (SKINNER, 1996, p. 289). Nessa perspectiva, o caminho para a salvação, que o homem percorre no exercício da fé na justiça de Deus, é o da Graça divina [sola Gratia], concedida como redenção e justificação misericordiosa àqueles predestinados para a salvação como um favor "fora de proporção com nenhum mérito humano" (SKINNER, 1996, p. 290). Ao homem, caberia alcançar a fiducia: uma fé passiva, uma confiança na justiça de Deus. Lutero esclarece: “Crer ou não crer é assunto da consciência de cada um. [...] A fé é um ato livre, que não se pode impor a ninguém. É até uma obra divina do Espírito. Não se pode nem pensar que alguma autoridade externa possa impor ou cria-la.” (LUTERO, 2017b, p. 51).

Nesses termos, Lutero constituiu uma nova teologia, orientada pela ideia da justificação somente pela fé [per sola fide], que não apaga os pecados cometidos pelo fiel, mas garante que eles deixem de pesar contra ele. Skinner esclarece que

a justiça do crente jamais é domestica - nunca é atingida, menos ainda merecida, por ele. Só pode ser-lhe extranea - uma "justiça estranha, instilada em nós sem nossas obras, pela graça somente”. O fiel em qualquer ocasião é visto como simul justus et peccator - a um só tempo, pecador e justificado. (SKINNER, 1996, p. 290)

Essa dicotomia do homem simul justus et peccator reproduz no mundo aquela dicotomia anteriormente citada da face oculta e revelada de Deus, relacionando a justificação ao Deus oculto, este como causa eficiente daquela, e o pecador ao Deus revelado, este como causa formal da vida daquele, como via de salvação. Para Lutero, esse fiel "pecador e justificado" habita simultaneamente dois reinos coexistentes: o pecador, o reino do homem, e o justificado, o reino de Deus. Cada reino opera com conceitos distintos e complementares de justiça, que ocupam lugar central no pensamento social e político de Lutero. De um lado, a justiça divina, primária e passiva que os 
cristãos podem atingir no reino de Deus e, de outro, a "justiça ativa ou civil, que não faz parte da salvação, mas continua sendo essencial para uma adequada regulação dos assuntos deste mundo” (SKINNER, 1996, p. 291). A primeira opera por leis divinas conforme o arbítrio de Deus, orientando seu povo para a salvação conforme sua benevolência e a luz de sua graça. A segunda opera de acordo com as leis dos homens, conforme o arbítrio das autoridades seculares, orientando o povo para a vida em comunidade e a construção da paz e do bem comum na terra (LUTERO, 2017a, p. 22, 24).

Para Pelikan (apud SKINNER, 1996, p. 292), o princípio luterano da sola fide, que constitui o único meio pelo qual o cristão pode esperar a salvação, restitui ao homem uma relação direta com Deus, negando a autoridade instituída da Igreja e seu poder de intermediação nessa relação. De fato, para Lutero, a Igreja poderia ser identificada simplesmente como Gottes Volk, o "povo de Deus, vivendo da palavra divina” (BORNKAMM, apud SKINNER, 1996, p. 293).

Skinner (1996, p. 293) enfatiza que Lutero empenhou-se em propagar a ideia de que todo indivíduo poderia relacionar-se diretamente com Deus, sem necessidade de qualquer intermediação, e que todo cristão pertenceria ao reino Dele, já que nele figurariam, não em virtude de seu papel ou posição na sociedade, mas apenas graças à sua igual condição para a fé, a capacidade de ser "espiritual e [de constituir] um povo cristão", uma ecclesia [igreja] como uma congregatio fidelium [uma comunidade na fé] na qual prevaleceria a ideia do sacerdócio de todos os fiéis. Skinner constata que

esse conceito e suas implicaçốes sociais aparecem mais desenvolvidos no seu [de Lutero] célebre Manifesto de 1520, dirigido "à nobreza cristã da nação germânica". O reformador aqui argumenta que, se a Igreja é apenas Gottes Volk, só pode haver "engodo e hipocrisia" na pretensão de que "papa, bispo, padres e monges sejam chamados estado espiritual, enquanto aos príncipes, senhores, artesãos e lavradores se chama estado temporal". (SKINNER, 1996, p. 293)

Outra característica da teologia luterana resulta do significado que Cristo assume nela, enquanto parte da face revelada de Deus contida nas Sagradas Escrituras. Skinner constata que é "por meio de Cristo que os homens receberiam o conhecimento da graça redentora de Deus, assim como seria por esse mesmo caminho que ele se emanciparia das exigências inatingíveis da lei, e a ele chegaria a 'boa-nova' de que a salvação seria possível” (SKINNER, 1996, p. 292). Assim, a teologia luterana constitui-se como uma theologia crucis [teologia da cruz], que reconhece apenas no martírio 
e no sacrifício de Cristo [solus Christus] as chaves para a salvação. Dessa forma, segundo Siggins (apud SKINNER, 1996, p. 292) Cristo passa a ser reconhecido como “o único pregador” e "o único salvador", que não apenas liberta o homem do fardo dele nada valer moralmente pela força redentora de Seu mérito e amor, como também serve de "fonte e conteúdo do fiel conhecimento de Deus”.

O princípio da sola fide, que propóe a confiança na justiça de Deus, associado à ideia da theologia crucis - solus Christus, que apresenta o Cristo revelado como o caminho da Graça, orienta a formulação do postulado da sola Scriptura [apenas a Escritura], que propóe a palavra divina como único caminho válido de acesso a Cristo e, por conseguinte, a Deus e ao exercício da fé, negando a traditio [tradição] católica como deturpação dos textos religiosos e distanciamento de Deus, a mediação da Igreja e a autoridade de seus representantes, e afirmando a importância da livre leitura e interpretação da Bíblia pela comunidade de fieis (HANSEN, 2019, p. 55). Nesse sentido, Lutero assevera que "se a Palavra de Deus não está presente, é duvidoso se Deus o quer assim. Quando ele não o ordena, não podemos ter a certeza de que lhe agrada. Pelo contrário: há a certeza de que não agrada a Deus. Pois ele quer que nossa fé se baseie apenas e exclusivamente em sua Palavra divina”. (LUTERO, 2017b, p. 46-47)

Nessa perspectiva, reconheço ainda com Hansen que

\footnotetext{
a tese luterana da sola scriptura foi materialmente condicionada pela imprensa, que tornava acessíveis os originais dos textos bíblicos. [...] Lutero pressupunha que o acesso às novas traduçóes dos originais hebraicos e gregos permitiria retomar a pureza das fontes escriturais desvirtuadas pelas tradiçôes dos homens. Os erros das traduçôes, que a Igreja interpretava e continuou a interpretar como intervençôes da Providência divina, deveriam ser eliminados para se repor a doutrina em sua pureza original. (HANSEN, 2019, p. 57)
}

Vlastuin (2018), assim como Hansen (2019), associa esses “erros de tradução” à interferência de testemunhos decorrentes da transmissão oral da fé e de revelações, que constituíram a tradição católica como fonte autorizada do texto sagrado vinda diretamente "da própria boca de Cristo", distinguindo-os da interpretação das Escrituras, que era considerada válida, desde que se mantivesse restrita ao texto sagrado original. Vlastuin esclarece que 
Lutero não nega a importância da igreja enquanto o corpo de Cristo, mas aceita as implicações de seu entendimento acerca da autoridade das Escrituras baseando-se na distinção entre a autoridade do corpo de Cristo e a da Palavra de Cristo, de modo que a autoridade final recaia sobre as Escrituras e não sobre a igreja, sem com isso rejeitar a tradição da interpretação das Escrituras. [...] Seguindo com H. A. Oberman, nós podemos falar da aceitação de uma 'tradição I' como uma tradição interpretativa das Escrituras e da rejeição de uma 'tradição II' na qual a tradição era compreendida como revelação' ${ }^{1}$. (VLASTUIN, 2018, p. 247, tradução nossa)

Nessa perspectiva, podemos entender a recomendação de Lutero, que aconselha:

quem toma por certo aquilo que é errado e incerto nega a verdade, que é o próprio Deus. [...] O máximo da loucura é quando mandam que se creia na igreja, nos Pais da igreja, nos concílios, mesmo quando não há Palavra de Deus. Os apóstolos do diabo ordenam tais coisas, e não a igreja. [...] Estão longe de provar que as decisões dos concílios sejam Palavra de Deus. [...] Ninguém pode ou deve dar ordens à alma, a não ser que saiba mostrar-lhe o caminho do céu. Mas isso nenhum ser humano pode, somente Deus. Portanto, nas questóes que dizem respeito à bem-aventurança da alma, nada deve ser ensinado ou aceito senão a Palavra de Deus. (LUTERO, 2017b, p. 47-48)

De acordo com esses princípios, podemos reconhecer com Skinner (1996, p. 292) que "a teologia luterana constituiu as estruturas que orientaram o confronto entre o movimento da reforma protestante e o da contrarreforma católica”. Essas estruturas surgiram da própria contestação das ideias e princípios católicos, como respostas que negavam práticas vigentes e instituíam novas práticas, moldando uma nova visão de mundo. Foi a partir dessa visão que se constituíram os princípios políticos que passaram a vigorar nesse novo contexto.

A teologia de Lutero gerou pelo menos duas implicações políticas que, somadas, constituem o que se considera mais distintivo de seu pensamento social e político. Em primeiro lugar, Lutero nega a jurisdição política da Igreja e a autoridade dela para dirigir e regular a vida cristã (SKINNER, 1996, p. 294), afirmando a natureza espiritual da 'verdadeira' igreja - a congregatio fidelium - e da doutrina. No Manifesto de 1520, dirigido à nobreza cristã da nação alemã, Lutero declara que:

\footnotetext{
${ }^{1}$ Luther did not deny the importance of the church as the body of Christ, but he accepted the implications of his understanding of the authority of Scripture by making a distinction between the authority of the body of Christ and the Word of Christ, so that the ultimate authority lies with scripture and not with the church, without rejecting the tradition of the interpretation of scripture. In accordance with H.A. Oberman we can speak of the acceptation of 'Tradition I' as an interpretative tradition of scripture and a rejection of 'Tradition II' in which tradition was understood as revelation.
} 
É pura invenção que o papa, os bispos, padres e monges devam ser chamados de "classe espiritual”; príncipes, senhores, artesãos e camponeses de "classe secular". Isso é, de fato, uma invenção e um engano muito sutil. Ainda assim, ninguém deve ser intimidado por isso; e por este motivo: na verdade, todos os cristãos são a "classe espiritual", e não há entre eles diferença alguma, a não ser a ocupação que possuem, como Paulo afirma em 1Coríntios 12.12: somos todos um único corpo, ainda que cada membro tenha seu próprio trabalho, por meio do qual serve os outros. Como consequência, temos um batismo, um evangelho, uma fé e somos cristãos da mesma classe; pois o batismo, o evangelho e a fé, e só eles nos tornam "espirituais” e um povo cristão. Entretanto, que o papa ou um bispo unge, tonsura, ordena, consagra e se veste de modo distinto dos leigos, isso pode gerar hipócritas e ídolos, porém jamais gera um cristão, ou uma pessoa "espiritual". Portanto, por meio do batismo todos somos consagrados como sacerdotes, como Pedro afirma em 1Pedro 2.9: "vós sois geração eleita e sacerdócio real”, e o livro de Apocalipse: "por meio do teu sangue nos constituíste sacerdotes e reis" (Ap 5.10). Assim, se não houvesse uma consagração superior àquela concedida pelo papa ou pelos bispos, essa consagração por eles jamais tornaria alguém padre, nem autorizaria alguém a celebrar a missa, pregar um sermão ou conceder absolvição. (LUTERO, 2017a, p. 82)

Inicialmente, Lutero nega a existência de uma classe espiritual e de uma classe secular. Conforme sua concepção teológica, todos os cristãos são iguais perante Deus e participam igualmente do reino espiritual por meio do batismo, do evangelho e da fé. No reino secular, o que distinguiria um sacerdote de um príncipe, senhor, artesão ou camponês seria apenas a função que cada um desempenha no corpo social, que está destinado a preservar a ordem e a paz e a promover o bem comum, pelo exercício mútuo do servir regulado pela conveniência (LUTERO, 2017a, p. 83). Com relação a isso, Lutero esclarece:

O que são os sacerdotes e bispos? Resposta: seu regime não é de autoridade ou poder, mas serviço e função. Não são superiores e melhores do que outros cristãos. Por isso não devem impor lei ou mandamento a outros sem a vontade e aprovação desses. Seu governo não é outra coisa senão pregar a Palavra de Deus e com ela orientar os cristãos a vencer a heresia. (LUTERO, 2017b, p. 66)

Não seria conveniente para a ordem social que todos desempenhassem as mesmas funçôes e, por essa razão, alguns se tornam sacerdotes, outros camponeses, outros cozinheiros, e assim por diante. Nesse sentido, Lutero define o verdadeiro cristão como aquele que "não vive na terra para si mesmo, mas para o próximo e lhe serve. Pela natureza de seu espírito, faz também aquilo que não precisa, mas que é útil e necessário para seu próximo” (LUTERO, 2017b, p. 27). Nessa perspectiva, replica nas relações sociais o regime de servidão conveniente que subordina uns aos outros garantindo a manutenção da estrutura e das funções sociais vigente. Assim, Lutero conclui: 
Disso resulta que, na verdade, não há diferença entre leigos, padres e bispos, ou entre “espirituais" e "seculares", como os denominam, exceto o ofício e a ocupação, mas não a “classe”, pois todos pertencem à mesma classe - padres, bispos e papas verdadeiros embora não estejam todos envolvidos na mesma ocupação, assim como padres e monges não possuem o mesmo trabalho. (...) Portanto, como os que agora são chamados de “espirituais" - padres, bispos ou papas - não são diferentes de outros cristãos nem superiores a eles, exceto que são incumbidos da administração da Palavra de Deus e dos sacramentos, que é o seu trabalho e seu ofício, assim também ocorre com as autoridades seculares: elas fazem uso da espada e da vara para punir os que fazem o mal e para proteger os piedosos. Um sapateiro, um ferreiro, um agricultor, cada um tem o seu ofício e trabalho. Ainda assim, todos eles são igualmente consagrados padres e bispos, e cada um deve ser útil e servir ao próximo com seu ofício ou trabalho, para que desse modo muitos tipos de trabalho possam ser realizados para o bem-estar do corpo e da alma da igreja, ao mesmo tempo que todos os membros do corpo servem uns aos outros. (LUTERO, 2017a, p. 84)

Lutero concebe o corpo social do Estado também como corpo espiritual, como o corpo de Cristo, que é a cabeça que a tudo comanda e dirige. Todos aqueles que participam do corpo servem uns aos outros e à cabeça. Cristo não tem dois corpos distintos, um "secular" e outro "espiritual". Ele é apenas uma cabeça e tem, portanto, um corpo apenas.

A distinção entre reino espiritual e secular distingue os cristãos dos não cristãos, pois, ao passo que os primeiros habitam ambos os reinos simultaneamente, na unidade do corpo de Cristo, os segundos habitam apenas o reino secular e não participam do reino espiritual, pois não foram batizados, não conhecem o evangelho e não compartilham da mesma fé. Para esses últimos, segundo Lutero, Deus teria ordenado o poder secular "para punir os malfeitores e proteger os que fazem o bem” (LUTERO, 2017a, p. 84). Segundo essa perspectiva, o poder secular teria origem divina e seu representante teria total autonomia e liberdade para exercê-lo no exercício de sua função, sobrepondo-se inclusive aos representantes da igreja, uma vez que sua função assim o determina. Lutero considerava que, se o imperador ou os príncipes-eleitores cristãos não pudessem exercer sua função na gestão do reino secular, em benefício de todos, igualmente não poderiam exercê-lo os alfaiates, sapateiros, pedreiros, carpinteiros, cozinheiros, agricultores e todos os demais agentes que compóem o corpo social do Estado, assim como estariam impedidos os próprios sacerdotes. Nesse sentido, para Lutero, o poder secular não se subordina à igreja, pelo contrário, ela se subordina a ele, haja vista sua origem divina e sua função social. Assim, como consequência, Lutero rejeitou por completo o direito canônico, declarando falsa a mediação da Igreja para a salvação, assim como sua autoridade e a de seus agentes instituídos. Reconheço com Skinner (1996, p. 296) que, quando 
Lutero trata sobre o poder do reino espiritual, "tem em mente uma forma de governo puramente interna, 'um governo da alma', sem nenhuma relação com os assuntos temporais, e inteiramente dedicado a socorrer os fiéis no rumo da salvação”.

Lutero fundamentou sua ideia na interpretação das Escrituras, em especial do Novo Testamento, do qual ele recupera textos dos apóstolos Paulo e Pedro, que afirmaram a origem divina do poder secular e a sujeição de todos à autoridade que esse poder institui:

Pois Paulo lembrou todos os cristãos: "Que cada alma (com isso quero incluir também a alma do papa) deve sujeitar-se às autoridades; pois não carregam a espada em vão; pois são servos de Deus para punir os malfeitores; e para louvor daqueles que fazem o bem" (Rom 13.1). Pedro também afirma: "Sujeitai-vos a toda autoridade humana por causa de Deus, pois essa é a sua vontade” (1Pe 2.13). Ele também anunciou que tais homens virão e desprezarão as autoridades seculares (2Pe 2.10); e isso ocorreu por meio da lei canônica. (LUTERO, 2017a, p. 85)

Essa compreensão foi reafirmada no tratado publicado por Lutero em 1523, intitulado Da autoridade secular que, segundo Skinner (1996, p. 296), constitui-se como um dos documentos mais importantes do pensamento social e político de Lutero.

Lutero iniciou esse texto de 1523 retomando as mesmas referências do Novo Testamento citadas anteriormente, para reafirmar que todo poder secular que existe no mundo só existe "por vontade e ordem de Deus” (LUTERO, 2017b, p. 14). O uso desse poder deveria ter como objetivo "levar o povo à perfeição e ensiná-lo de maneira cristâ", castigando os maus e protegendo os piedosos (LUTERO, 2017b, p. 16). A essa divisão dos homens corresponderiam as categorias de não-cristãos e cristãos, respectivamente. E, uma vez que os cristãos "têm no coração o Espírito Santo, que os ensina e não os deixa fazer mal a ninguém” (LUTERO, 2017b, p. 19), o poder secular teria sido constituído apenas para governar os maus e não-cristãos que, por serem conduzidos por sua natureza decaída, precisariam da lei e da espada como mecanismos externos de regulação que os obrigassem e pressionassem a agir bem. De fato, lembra Lutero com Paulo (cf. Romanos 3.23), “nenhum ser humano é cristão e justo por natureza, mas todos são pecadores e maus” (LUTERO, 2017b, p. 20). Aqueles cuja natureza não fosse corrigida diretamente pela fé e pela Graça, seria corrigida indiretamente pela lei secular e pelo poder da espada. Lutero lembra ainda com São Paulo (cf. Romanos 7.7 e Gálatas 2.1) que a lei secular, além de inibir o mal comportamento, cumpriria 
ainda outra função, de natureza pedagógica, na medida em que ela ensinasse a reconhecer o pecado, tornando o ser humano humilde para a Graça e a fé em Cristo. Finalmente, o reformador constata que "é preciso diferenciar com cuidado entre esses dois regimes e deixá-los vigorar: um que torna justo, o outro que garante a paz exterior e combate as obras más. Sozinho, nenhum dos dois basta no mundo" (LUTERO, 2017b, p. 24) e ambos precisariam estar sempre integrados.

Além de negar a jurisdição política da Igreja e sua autoridade, a teologia-política de Lutero afirmava a origem divina do poder secular, seu domínio sobre a Igreja e a submissão de todos perante Deus. Lutero entendia que a autoridade secular, no exercício da administração do reino temporal, era também "servidora de Deus" e servi-la equivaleria a servi-Lo, posto que "a autoridade é de tal natureza que se pode servir a Deus por meio dela” (LUTERO, 2017b, p. 37), conforme a necessidade, e posto que é função do cristão servir a Deus e que não haveria serviços para Deus que um cristão não pudesse ou não devesse realizar.

Além disso, o campo de atuação da autoridade secular é limitado pela condição temporal, material e contingente do mundo em que ela opera, preservando o mundo espiritual para a ordem de Cristo, que é Deus. Essa referência orientava o julgamento da ação cristã no mundo e a obediência à autoridade secular, conforme prescreve Lutero, retomando novamente as ideias de São Paulo: "São Paulo observa que a obediência e o poder temporais referem-se apenas externamente a tributo, imposto, honra e respeito. [...] Com isso, ele restringe ainda mais a competência da autoridade: ela existe não para dominar a fé e a Palavra de Deus, mas a obra ruim” (LUTERO, 2017b, p. 55). E conclui enfaticamente: “sem dúvida, a pessoa humana recebeu poder de Deus sobre aquilo que está na terra e pertence ao reino terreno e temporal. Mas aquilo que se relaciona com o céu e o reino eterno está sob a exclusiva autoridade do Senhor do céu (LUTERO, 2017b, p. 56). Nessa perspectiva, discordo parcialmente de Hansen, quando afirma que "sendo enviados por Deus, os reis [luteranos] têm autoridade para legislar em matérias de poder espiritual, dispensando a auctoritas delegada por Cristo ao Papa” (HANSEN, 2019, p. 58). De fato, o poder da autoridade secular dispensava o poder político do Papa no reino temporal, contudo, a autoridade secular não tinha poder sobre as coisas do mundo espiritual, conforme esclarece Lutero.

Com Skinner, assumo que o fato de a igreja ser colocada sob o controle de um príncipe devotado à religião não implica que esse príncipe seja convertido em sacerdos, "nem que a ele se 
atribua qualquer autoridade a emitir juízos sobre o conteúdo da religião. Seu dever consiste simplesmente em favorecer a pregação do Evangelho e em defender a verdadeira fé” (SKINNER, 1996, p. 297). Com relação a isso, Cesca (apud BARBOSA, 2011, p. 872) acrescenta que, "entre Igreja e Estado haveria uma linha de continuidade, não na sua origem, mas na sua finalidade” e Barbosa pondera que "apesar de Lutero sugerir competências distintas para Igreja e Estado, ele não os teria separado como instâncias autônomas. O Estado limitava e regulamentava a Igreja enquanto instituição social e esta proclamava a vontade de Deus àquele” (BARBOSA, 2011, p. 872). Nesse caso, portanto, o Estado era concebido como uma instituição também cristã e Lutero não cogitava a secularização dele no âmbito político.

Finalmente, cabe destacar que o modelo proposto por Lutero para ser seguido pelas autoridades seculares é o de Cristo, concebido como o príncipe dos príncipes, que, num gesto de amor, serviu ao próximo com humildade. Nesse sentido, Lutero propõe:

O príncipe vai fixar seus olhos em Cristo e dizer: "Eis que Cristo, o príncipe supremo, veio e me serviu; não procurou poder, bem e honra em mim, mas viu minha necessidade e fez tudo para que eu tenha poder, bem e honra por seu intermédio. Por isso farei o mesmo. [...] Quero proteger, ouvir e defendê-los [os súditos] e governar apenas para que tenham bens e proveito, e não eu." (LUTERO, 2017b, p. 71)

Nesses termos, Lutero procurou relativizar as relaçóes de poder secular, reconhecendo a materialidade e a contingência desse poder estabelecidas pelos referenciais ético-políticos da própria religião, e a finalidade do próprio poder: a promoção da felicidade social e do bem comum. Assim, ainda que as diferenças de classe e posição social fossem preservadas, as distâncias eram diminuídas, pelo menos no discurso e na intenção, uma vez que as práticas principescas relatadas por Lutero eram bastante diversas (LUTERO, 2017b, p. 53). Com isso, não pretendia ensinar os príncipes a viver, mas sim mostrar-lhes o modo de vida cristão que lhes possibilitasse alcançar o céu, assim como todos aqueles que estivessem sob sua espada, uma vez que os próprios príncipes estariam subordinados a Deus e deveriam fazer por merecer, eles também, alcançar a salvação (LUTERO, 2017b, p. 72, 81). 


\section{A educação como instrumento promotor da teologia-política de Lutero}

Dentre os escritos de Lutero sobre educação, destacam-se os manifestos dirigidos "À nobreza cristã da nação alemã, acerca da melhoria do estamento cristão", de 1520; "Aos conselhos de todas as cidades da Alemanha para que criem e mantenham escolas cristãs", de 1524, e "Uma prédica para que se mandem os filhos à escola”, de 1530 (LUTERO, 1995). Nesses textos, Lutero parte de seus fundamentos teológico-políticos para propor reformas também no âmbito da educação, de maneira que ela atendesse efetivamente à função para a qual ela fora concebida, cumprindo seus objetivos como instrumento de Estado dedicado à promoção da fé, da ordem e do bem-estar social.

Uma vez que, para Lutero, não deveria existir uma instituição que acumulasse e exercesse o poder espiritual, mas, em contraposição, esse poder deveria ser exercido coletivamente e individualmente por todos os cristãos, que assumiriam e exerceriam sua função social conforme a conveniência coletiva e a vocação individual, podemos entender que, no exercício dessa função, do servir ao outro, cada um da sua maneira, todos atuariam por Cristo, sob Cristo e com Cristo. Devemos considerar também que, de acordo com a doutrina de Lutero, os cristãos nunca deveriam agir conforme seus próprios interesses, mas guiados apenas pela consecução do bem comum. Assim, a função e o fazer de cada um são concebidos como uma função e um fazer autorizados e guiados por Deus e, nesse sentido, a desobediência entre cristãos e o não cumprimento do servir e da função para qual se era evocado seriam compreendidos como a desobediência a Deus também. Dessa forma, manifesta-se Lutero e apresenta os princípios de sua doutrina em seu manifesto de 1524, exortando as cidades da Alemanha para que criem e mantenham escolas cristãs:

não procuro meu próprio interesse nesta causa (isso eu o alcançaria muito melhor se silenciasse). Tenho as melhores intenções convosco e com toda a Alemanha; pois foi para isso que Deus me destinou, que o creia ou deixe de acreditar quem quiser. E quero ter prometido e anunciado de modo franco e confiante a vosso amor: se me obedecerdes neste ponto, sem dúvida não obedeceis a mim, mas a Cristo. E quem não me obedece, não despreza a mim, mas a Cristo. Pois sei, em todo caso, e estou certo do que falo e ensino e com que objetivo; isso certamente também o sentirá todo aquele que se der ao trabalho de observar minha doutrina corretamente. (LUTERO, 1995, p. 303)

Lutero inicia seu manifesto fazendo uma avaliação do sistema educacional vigente e destacando a inadequação das práticas instituídas em relação à função que deveriam cumprir no 
contexto escolar. Relata que as escolas estavam abandonadas, as universidades eram pouco frequentadas e os conventos estavam em declínio, constatando que ninguém mais queria proporcionar ensino e estudo aos seus filhos. Esse estado de coisas resultava do desvio de função dessas instituições que, segundo o reformador, eram procuradas pela população apenas para o "bem-estar da barriga e alimento material para os filhos" (LUTERO, 1995, p. 304) e, tendo em vista a decadência do estado clerical naquele momento, reconhecia-se que não mais interessava a formação que essas instituiçốes proporcionavam. Lutero assevera que verdadeiros pais, cristãos e fiéis não deveriam preocupar-se apenas com o sustento dos filhos, mas também com sua alma, e deveria ser para a elevação dela que as escolas deveriam operar.

A educação dos jovens é reconhecida por Lutero como uma das questões de maior importância para a constituição do Estado, sendo reconhecida como a solução para os problemas do mundo temporal. Sendo assim, deveria ser tratada com a mais "profunda seriedade cristã" (LUTERO, 1995, p. 305). Sua manutenção deveria ser responsabilidade do Estado, de modo que assegurasse igualdade de oportunidades a todos, pelo menos na formação necessária para o acesso às Escrituras. Lutero reconhecia que o investimento na educação era caro e dispendioso, mas necessário, pois incentivaria e fortaleceria a fé e as bases do reino de Deus e, consequentemente, promoveria o enfraquecimento do reino do mal (Ibid.). Por isso, conclamou aos dirigentes das cidades alemãs para que gastassem "com o sustento de professores o mesmo que se gastava com armas, estradas, pontes, diques e outras coisas que garantem a paz e a segurança temporal” (Ibid.) e orientou a população para que doasse às escolas o dinheiro que antes era doado à igreja para indulgências, missas, vigílias, espólios, e outras práticas congêneres, "pela Graça de Deus, para sua Glória e em Seu agradecimento” (Ibid.)

O investimento nas escolas, segundo Lutero, se justificava também, naquele momento, pelo aproveitamento da boa safra de jovens professores disponíveis na Alemanha, "os melhores e mais doutos jovens companheiros e homens com conhecimento linguístico e toda a ciência”, que poderiam produzir algo "útil se fossem aproveitados para instruir a juventude” (LUTERO, 1995, p. 306). Essa situação foi reconhecida por Lutero como uma graça de Deus, que deveria ser aproveitada em agradecimento e louvor a Ele, e não desprezada ou ignorada, pois a ingratidão e o desprezo poderiam resultar em punição, trevas e pragas. 
Finalmente, justifica a necessidade de investimento na educação pelo cumprimento de uma função intergeracional, declarando que

\begin{abstract}
para que vivemos nós velhos senão para cuidar da juventude, ensinar e educá-la? Pois é totalmente impossível esperar que este povinho louco [a juventude] se instrua e discipline a si mesmo; por isso Deus os confiou a nós, os mais velhos e que sabemos por experiência o que serve para o bem deles, e, sem dúvida, exigirá de nós uma prestação de contas severa sobre eles. (LUTERO, 1995, p. 307)
\end{abstract}

Lutero reconhece que é próprio da natureza humana que as geraçóes anteriores eduquem as gerações posteriores. Aliás, para ele, a razão principal da existência humana seria a educação da juventude. Contudo, constata que inúmeros pais não se dedicavam a essa tarefa, o que poderia ser compreendido, segundo ele, por três razóes. Primeiro, por não terem consciência dessa obrigação, uma vez que sua natureza estaria corrompida; segundo, por não terem aptidão para a educação e, terceiro, por falta de tempo e espaço adequados para o exercício dessa atividade. Assim, justifica veementemente a necessidade de que os estados mantivessem educadores comunitários para as crianças e jovens. (LUTERO, 1995, p. 308)

$\mathrm{Na}$ medida em que se configurava o dever do estado secular de prover a educação a todos, os conselhos e autoridades municipais passaram a assumir a responsabilidade "social e cristâ" de garantir o "progresso" e o melhoramento da cidade, dedicando o maior cuidado e o máximo empenho à juventude. Para Lutero, que reconhecia a educação romana antiga como ideal, a ideia de progresso associava-se de forma diretamente proporcional ao número de homens bem instruídos, ajuizados, honestos e bem-educados que viviam nas cidades, e essa formação dependia, em suma, das instituiçóes de ensino (LUTERO, 1995, p. 309).

Somava-se à justificação da necessidade das escolas a ideia de que elas se constituíam como instrumento de estado para a manutenção do próprio regime secular, que dependia de indivíduos bem formados para seu bom funcionamento. Lutero afirma que "sempre há de haver um regime secular" e sua manutenção dependeria do serviço de "pessoas decentes, instruídas e aptas para o governo" acompanhado do esforço e da preocupação para que tudo funcione bem (LUTERO, 1995, p. 310). Manacorda (2010, p. 242) reconhece que "o acento [da proposta de Lutero] é colocado especialmente na utilidade social da instrução, destinada a formar homens capazes de governar o Estado e mulheres capazes de dirigir a casa”. 
Além de justificar a necessidade das escolas, Lutero formula proposta de currículo, indicando os conhecimentos necessários para a formação almejada. Esse currículo, de caráter humanista, conforme especifica Cambi (1999, p. 250), enfatiza o estudo das línguas antigas (grego, hebraico e latim), as línguas modernas (em particular o alemão), as artes liberais, a história e as ciências. $\mathrm{O}$ estudo das línguas é justificado, numa perspectiva cristã, pelo acesso que elas viabilizam às Sagradas Escrituras. Aliás, a palavra, signo da racionalidade humana, é reconhecida por Lutero como um "maravilhoso e nobre dom de Deus", com o qual Ele comunicou seu evangelho, se fez presente entre os homens e é assim preservado, como "bainha da espada do Espírito”. Nesse sentido, em seu manifesto de 1524, Lutero declara:

Porque não podemos negar: embora o Evangelho, tenha vindo até nós exclusivamente pelo Espírito Santo e ainda venha diariamente, isso aconteceu por intermédio da linguagem e através dela se desenvolveu; e por meio dela também há de ser preservado. Pois quando Deus quis levar o Evangelho a todo o mundo por meio dos apóstolos, deu concomitantemente também as línguas. (LUTERO, 1995, p. 311)

$\mathrm{Na}$ medida em que foram reconhecidas como dom de Deus, as línguas deveriam ser usadas com rigor, responsabilidade e cuidado, e sua desvirtuação configuraria grave transgressão. Para Lutero, competiria ao cristão ler a Bíblia e seria pecado e motivo de vergonha não a entender por não conhecer as línguas, não as estudar, especialmente quando Deus ofereceu pessoas e livros e todos os recursos necessários para isso, para que Seu livro fosse acessível a todos (LUTERO, 1995, p. 315). Nesses termos, para a falta de dedicação aos estudos e a ingratidão, Lutero apresenta o rigor de Deus para o castigo e a punição. Onde, porém, houvesse o conhecimento das línguas, aí haveria o estudo das Escrituras e a renovação da fé, a Graça e a salvação.

Para Lutero, a escola deveria constituir-se como um espaço dedicado a uma educação atraente, prazerosa e adequada aos jovens. Destaca que

a juventude tem que dançar e pular e está sempre à procura de algo que cause prazer. Nisto não se pode impedi-la e nem seria bom proibir tudo. Por que então não criar para ela escolas deste tipo e oferecer-lhe estas disciplinas? [...] Falo por mim mesmo: se eu tivesse filhos e tivesse condiçôes, não deveriam aprender apenas as línguas e História, mas também deveriam aprender a cantar e estudar Música com toda a Matemática. (LUTERO, 1995, p. 319) 
Lutero compreende, para que esse novo projeto de escola fosse bem sucedido, seria necessário que os problemas apresentados pelo projeto anterior fossem solucionados, tais como o esvaziamento das instituiçóes de ensino e a falta de interesse nelas pela sociedade. Assim, propôs um modelo mais flexível, mais próximo das demandas do mundo do trabalho e das expectativas dos estudantes e da sociedade. Ele esclarece:

\footnotetext{
Minha ideia é a seguinte: Os meninos devem ser enviados a estas escolas diariamente por uma ou duas horas e, não obstante, fazer o serviço em casa, aprender um ofício ou para o que sejam encaminhados, para que as duas coisas andem juntas enquanto são jovens e podem dedicar-se a isso. Do contrário, gastam dez vezes mais tempo com jogos de bolinhas, jogar bola, corridas e lutas. Também uma menina pode dispender diariamente uma hora para ir à escola e, ao mesmo tempo, cumprir perfeitamente suas tarefas domésticas. [...] Os destaques dentre eles, porém, dos quais se esperaria poderem tornar-se pessoas qualificadas para o cargo de professores e professoras, pregadores e outros cargos clericais, a esses têm que se proporcionar um estudo mais prolongado e intensivo ou, até destiná-los exclusivamente ao estudo. (LUTERO, 1995, p. 320)
}

Conforme observa Manacorda (2010, p. 242), Lutero procura conciliar o respeito pelo trabalho manual produtivo com o tradicional prestígio do trabalho intelectual, orientando sua proposta pela utilidade social da instrução, garantindo espaço para todas as classes de funções e trabalho. Cambi (1999, p. 249) complementa essa observação, afirmando que a concepção pedagógica de Lutero "baseia-se num fundamental apelo à validade universal da instrução, a fim de que todo homem possa cumprir os próprios deveres sociais”, quaisquer que fossem.

Finalmente, Lutero apela às autoridades a quem se dirige, alegando a urgência de sua demanda e recorrendo ao compromisso cristão com o servir:

\footnotetext{
Por isso é urgente, não apenas por causa dos jovens, mas também para a preservação de nossos estados clericais e seculares, que se faça algo sério e a tempo neste sentido. [...] Por isso, caros senhores, dedicai-vos à tarefa que Deus exige de vós tão insistentemente, que é do vosso dever, que é tão necessária para a juventude e da qual nem o mundo nem o espírito podem prescindir. (LUTERO, 1995, p. 321)
}

Manacorda constata que as demandas de Lutero tiveram tal força política que, na Dieta de Augusta, de 1549, o imperador Carlos V incorpora essa nova concepção de escola pública em seu decreto: 
As escolas são viveiros não somente de prelados e de ministros da Igreja, mas também de magistrados e de quantos com seus conselhos governam a cidade; e se elas são negligenciadas ou se corrompem, inevitavelmente, as Igrejas e os Estados estarão em perigo: portanto, é preciso ter muito zelo em instituí-las. (apud MANACORDA, 2010, p. 244)

Fica evidente nesta recomendação imperial a consciência político-social da escola como instituição que fundamenta o Estado e a Igreja. Nessa perspectiva, compreendo com Cambi (1999) o atendimento descrito às demandas de Lutero:

Graças à estreita colaboração entre a nova Igreja reformada e as autoridades civis, sobretudo as da Saxônia, efetua-se primeiro uma reorganização das escolas municipais e, sucessivamente, chega-se a fundar algumas escolas secundárias financiadas e controladas pelo Estado. Nascem assim os ginásios, que são os primeiros e mais duradouros núcleos da escola nacional alemã. (CAMBI, 1999, p. 250)

A teologia-política de Lutero e as doutrinas sociais que ele derivou dela rapidamente obtiveram aceitação oficial numa grande região ao norte da Europa. Segundo Fife (apud SKINNER, 1996, p. 302), "as primeiras iniciativas nesse sentido ocorreram na Alemanha, onde o eleitor da Saxônia, Frederico, o Sábio, tomou a iniciativa de proteger Lutero após sua excomunhão, em 1520”. Cinco anos depois, esta região se tornou um principado luterano. Nesse mesmo ano, o ducado da Prússia aderiu ao movimento luterano e, no ano seguinte, a Casa de Hesse. Skinner relata que,

em 1528, a relação dos príncipes germânicos que haviam deixado a Igreja católica incluía os duques de Brunswick e Schleswig, o conde de Mansfeld e o margrave de Brandenburgo-Ansbach; em 1534, a eles já se tinham somado os senhores de Nassau, Pomerânia e Württemberg. Várias cidades imperiais também se haviam convertido. Em 1525, os luteranos controlavam Altenburgo, Bremen, Erfurt, Gotha, Magdeburgo e Nuremberg; em 1534, eram igualmente suas Augsburgo, Frankfurt, Hanover e Estrasburgo. (SKINNER, 1996, p. 302) 


\section{O lugar da música na escola luterana}

Lutero atribuiu um lugar de destaque à música em sua proposta de reforma religiosa. Reconhecida como instrumento próprio da ação do Espírito Santo, conforme relatos das Escrituras - como por exemplo em II Reis 3:15 - a música ocupou o lugar seguinte ao da Palavra de Deus, a principal, se não a única fonte de conhecimento Dele. De fato, Lutero reconhecia na música uma origem divina, observando sua presença na natureza como manifestação da "voz" das coisas, e considerando que "desde o começo do mundo ela foi infundida e implantada em todas as criaturas, individualmente e coletivamente. Pois nada existe sem som, sem número sonoro” (LUTERO, 1979, p. 322).

Ao homem também foi concedida uma voz, um instrumento para a fala e o canto, que devia ser utilizado principalmente para o conhecimento de Deus e seu louvor, a exemplo dos santos profetas e patriarcas, que produziram

muitos hinos e salmos nos quais a palavra e a música se unem para mover as almas dos ouvintes, enquanto em outros seres vivos e corpos sonoros a música permanece uma linguagem sem palavras. Afinal, o dom da linguagem combinado com o dom da música foi dado apenas ao homem para que ele soubesse que ele poderia louvar a Deus com palavras e música, isto é, proclamar a Palavra de Deus por meio da música e ministrar doces melodias com palavras. (LUTERO, 1979, p. 323-324)

Em conformidade com a proposta agostiniana, Lutero concebeu a música como um dom de Deus que, infundido em todos os serem vivos, era considerado o mais apto a transmitir a palavra Dele (LUTERO, 1979, p. 322). Ela teria como matéria as Sagradas Escrituras, entendidas como poesia elevadíssima, a obra de criação por excelência, o grande poema do Artista Criador, que o juntou a esse outro poema que é o mundo. A tópica que relaciona o mundo - como livro de Deus - e as Sagradas Escrituras estendia-se na relação com a palavra e a música do homem, tanto mais sagradas quanto mais próximas dos textos divinos (BARTEL, 1997, p. 4). Ao prefaciar a coleção de motetos intitulada Sinfonias Agradáveis [Symphoniae iucundae], publicada por Georg Rhau em 1538, Lutero distinguiu a expressão musical humana das demais manifestações musicais encontradas na natureza pela associação com a palavra - signo da racionalidade do homem (LUTERO, 1979, p. 323-324). Mas não com qualquer palavra, e sim com aquela usada 
corretamente e para o bem, como as das Escrituras, ou qualquer outra reconhecida como de inspiração divina, ou ainda decorrente da imitação das anteriores, desde que comprometida com a Verdade.

Dessa forma, Lutero condicionou a prática musical de sua igreja à palavra, e elevou a música à condição de viva vox evangelii, ou seja, à condição de "voz viva de Deus", o meio mais eficiente de persuadir e educar para o bem supremo (LUTERO, 1979, p 323). Não só por sua natureza divina e seu potencial expressivo Lutero justificou o lugar atribuído à música na sua igreja reformada. Ele reconheceu nela um potencial pedagógico que poderia ser explorado na educação daqueles que a escutam, estudam e executam. Certamente, esse potencial foi posto a serviço da verdade divina, como se pode verificar no Prefácio ao Hinário Wittenberguense de 1524, no qual Lutero manifesta sua preocupação com a educação musical dos jovens:

[Os hinos publicados neste volume] foram arranjados a quatro vozes por nenhuma outra razão senão o meu desejo de que a juventude, a qual afinal de contas deve e precisa se educada na música e em outras artes dignas, tenha algo com que se livre das cançốes de amor e dos cantos carnais para, em lugar destes, aprender algo sadio, de modo que o bem seja assimilado com vontade pelos jovens, como lhes compete. Também não sou da opinião de que, pelo Evangelho, todas as artes devam ser massacradas e desaparecer, como pretendem alguns pseudo-espirituais. $\mathrm{Na}$ verdade, eu gostaria que todas as artes, particularmente a música, estivessem a serviço daquele que as concedeu e criou. (LUTERO, 2016a, p. 481)

Estas mesmas preocupações foram reafirmadas em 1545, em outro prefácio, considerado a última contribuição de Lutero para a hinologia, publicado no Hinário de Valentim Babst, no qual se lê: "os tipógrafos fazem muito bem em dedicar-se com afinco à impressão de bons hinos, tornando-os atraentes para as pessoas por meio de tudo quanto é ornamentação, para que sejam estimuladas a ter prazer na fé, gostando de cantar” (LUTERO, 2016b, p. 482).

Em ambos os prefácios, Lutero destaca os desvios de uso da linguagem musical, os arranjos a quatro vozes e a ornamentação, como formas válidas de ajustar o discurso musical ao público e à finalidade para a qual foi concebido, quais sejam, a juventude e outras pessoas, a fim de que a música os faça aprender algo sadio e com vontade, os estimule a ter prazer na fé e o gosto pelo canto. No Prefácio a todos os bons hinários, escrito por Lutero para introduzir um texto de Johann Walter, de 1538, o reformador especifica o modo de ação da música, ao afirmar que ela "silencia e prepara o 
coração para a palavra e verdade divina” (LUTERO, 2016c, p. 483). Nesse mesmo texto, Lutero reconhece que "dentre todos os prazeres sobre a terra não há maior que seja dado a alguém do que aquele que eu [a Dona Música] proporciono com meu canto e com certas doces sonoridades” e que “cada qual tem o direito desse prazer não ser pecado, mas, ao invés, agrada a Deus muito mais do que todos os prazeres do mundo inteiro", pois a música "destrói a obra do diabo e impede que muitos malvados matem" (Ibidem). Nesses termos, podemos compreender que o apreço de Lutero pela música fundamenta-se principalmente na justificação religiosa que ela proporciona: “ela destrói a obra do diabo" - infundindo a palavra e a verdade divina por meio do prazer que proporciona, estimulando a fé e constituindo um círculo virtuoso a partir do próprio gosto pela música. Assumindo o autogoverno como exercício da vida cristã, orientado pela autoconsciência de seus deveres, como propôs Lutero, pode-se reconhecer nessa ideia de música seu valor para o aprimoramento da ordem social e do regime político vigente. Nessa perspectiva, podemos também reconhecer o lugar ocupado pela música no currículo escolar e nas práticas de ensino das novas escolas luteranas.

Segundo Schünemann (apud BUTT, 1994, p. 1-2), duas ordenanças escolares preparadas sob a influência direta de Lutero, a de Ph. Melanchton para a Saxônia e a de J. Bugenhagen para Brunswick, ambas publicadas em 1528, estabelecem os princípios para a educação musical nessas escolas no século XVI. Nessas ordenanças, a música foi definida como uma atividade prática, orientada pelas disciplinas do trivium medieval (gramática, dialética e retórica), e reconhecida como algo a ser ensinado diariamente aos estudantes de todas as idades, após o almoço. A esse respeito, Lucas esclarece que "esta recomendação se fundamenta na crença médica de que a prática do canto auxiliaria na digestão, e é seguida por muitas ordenanças nos sécs. XVII e XVIII” (LUCAS, 2014, p. 82).

Apesar das recomendaçóes, Schünemann (apud BUTT, 1994, p. 2) assevera que apenas algumas escolas as seguiram com rigor. De fato, esclarece Butt,

É evidente que a música não foi sempre calorosamente acolhida por reformadores acadêmico-humanistas e que o status dela como um fundamento da educação não foi sempre tão seguro como Lutero pudesse ter desejado. Muitas ordenanças estabeleciam que o componente teórico da instrução musical fosse mantido ao mínimo e que nem tanto tempo fosse dedicado à música. $\mathrm{O}$ status preciso da música variava de escola para escola e a situação era mais complexa do que muitos estudos modernos assumiram; 
naquela época, assim como hoje, a música era ambiguamente relacionada a diversos elementos conflitantes no pensamento educacional. ${ }^{2}$ (BUTT, 1994, p. 2, tradução nossa)

Ainda assim, a relação entre as escolas e as igrejas garantiu que a música se constituísse como uma atividade sempre presente na vida escolar, mesmo que em graus variados. Aliás, foi a função religiosa da música que viabilizou isso, enfatizando ora sua prática pelo canto, ora sua teoria, "com toda a Matemática”, conforme sugerido por Lutero no Manifesto de 1524.

De acordo com Butt (1994, p. 6), as primeiras ordenanças luteranas determinavam que os livros didáticos deveriam ser tão concisos quanto possível e que, em relação à educação musical, os livros mais comumente utilizados no século XVI foram o Rudimenta musicae (1533/1537), de N. Listenius, e o Compendiolum musicae (1548), de H. Faber. Butt (ibid.) afirma não ser possível precisar se esses livros foram efetivamente utilizados pelos estudantes, mas, por outro lado, é possível considerar que, por sua circulação, eles formavam a base da instrução dos professores.

Além dessas produções, outras também foram elaboradas, constituindo uma bibliografia específica dedicada ao ensino da música. Dentre elas, Lucas destaca que

os primeiros livros destinados especificamente às escolas luteranas são de autoria de Martin Agricola, que pertenceu diretamente ao círculo de Lutero: Ein kurtz deudsche musica (1528); Musica instrumentalis deudsch (1529); Musica figuralis (1532); Musica choralis (1533), além do Rudimenta Musices (1539). Trata-se de obras voltadas para a prática musical, que apresentam os principais elementos da teoria musical quinhentista: solmização, mutação, tactus, modus, prolação etc. (LUCAS, 2014, p. 82)

Essas obras de Agricola, escritas em alemão, claramente refletem a proposta de Lutero que encerra seu Manifesto de 1524, onde se lê:

Por último, recomenda-se a todos aqueles que se interessam pela criação e manutenção de tais escolas e do estudo das línguas na Alemanha, que não se poupem esforços nem dinheiro para a instalação de livrarias ou bibliotecas, especialmente nas grandes cidades que tenham condições para tanto. Pois se quisemos preservar o Evangelho e todas as artes,

\footnotetext{
${ }^{2}$ Indeed it is clear that music was not always warmly embraced by humanistic academic reformers and that its status as a fundamental of education was not always as secure as Luther himself might have wished. Many ordinances required that the theoretical component of music instruction be kept to a minimum and that not too much time be allotted to music. The precise status of music varied from school to school and the situation was more complex than many modern studies have assumed; then, as now, music was ambiguously related to several conflicting elements in educational thought.
} 
há que registrá-lo por escrito em livros e ali deve ser fixado (como o fizeram os próprios profetas e apóstolos, como dito acima). E isso não somente para que os príncipes espirituais e seculares tivessem literatura para ler e estudar, mas também para que os livros bons sejam preservados e não se percam juntamente com as artes e línguas que agora temos pela graça de Deus. (LUTERO, 1995, p. 322)

A produção de material didático para as diversas áreas de conhecimento e, em particular, para a música, contribuiu para a sistematização do próprio conhecimento em si, sua difusão e conservação. Em relação à música, essa produção bibliográfica constituiu, desde o século XVI, uma vasta coleção de textos publicados dedicados aos principais ramos dessa arte, a saber, o teórico, o prático e o poético.

A sistematização e registro de uma poética musical era uma ideia recente no século XVI. Surge pela primeira vez no texto intitulado Música [Musica] de Nikolaus Listenius (ca. 1510-?), publicado em Nurenberg em 1549. Nesse texto, Listenius propôs uma tripartição da música, na qual cada ramo é definido por um fim específico: a musica theorica tem como fim o conhecimento adquirido por meio da razão; a musica practica tem como fim a ação em si de produzir som; e "a musica poetica tem como fim a obra musical consumada e registrada, de tal modo que sua existência independa da existência de seu criador” ${ }^{3}$ (LISTENIUS, 1549, f.a3v, tradução nossa). Os dois primeiros ramos eram considerados conforme a orientação medieval das artes liberais. $\mathrm{O}$ terceiro ramo, por sua vez, foi concebido como a sistematização do processo de composição musical, ou, dito de outra forma, a partir do referencial aristotélico (Aristóteles, 2005, p. 185-186), como a sistematização do hábito produtivo musical orientado pela razão, dedicado a gerar as coisas que podem ser de um modo ou de outro e cujo princípio está no criador e não na coisa criada.

Na sequência de Listenius, o músico Heinrich Faber (1500-1552), em 1550, em seu tratado intitulado Introdução à Música Prática [Ad musicam practicam introductio], também publicado em Nuremberg, igualmente concebe a música como uma disciplina tripartida em seus ramos teórico, prático e poético, e define esse último como aquele que "modela o poema musical” (FABER, 1550, p. f.B2r, tradução nossa). Já em 1563, Gallus Dressler (1533-1581), em seu texto intitulado

\footnotetext{
${ }^{3}$ Poetica, quae neque rei cognitione, neque solo exercitio contenta, sed aliquid post laborem relinquit operis, ueluti cum à quopiam Musica aut Musicum carmen conscribitur, cuius finis est opus consumatum et effectum. Consistit enim in faciendo siue fabricando, hoc est, in labore tali, qui post se etiam, artifice mortuo opus perfectum et absolutum relinquat.

${ }^{4}$ Poetica fingit musica carmina.
} 
Preceitos de Poética Musical [Praecepta Musicae Poeticae] define a poética musical como "a técnica de modelar o poema musical ", e avança em sua definição, diferenciando a poética da teoria e da prática musical e especificando a que tipo de produção ele se refere:

[A poética] distingue-se das partes restantes da música. A theorica examina atentamente, a practica canta. Esta [a poética] verdadeiramente compõe novas harmonias, e resta a obra completa mesmo depois de morto seu autor. A poética musical é dupla, evidentemente o contraponto improvisado e a composição. O contraponto improvisado (como o mesmo nome indica) é a pronunciação improvisada por diferentes vozes, extemporânea e instigada sobre o canto de alguém. Esta é a mais usual junto aos estrangeiros do que conosco, e que depende mais dos usos/costumes do que das regras [originadas a partir da composição] e que carece de menos vícios [deixada aqui para se tratar da composição], pois não se registra por escrito e não é comum transmiti-la aos estudantes ${ }^{5}$. (DRESSLER, 1563 , s. p., tradução nossa)

Em sua definição, Dressler claramente retoma a ideia de Listenius ao reafirmar a permanência da obra criada após a morte de seu compositor a partir do registro escrito dela, integra essa ideia àquela de Faber, ao restringir a produção à música da poesia e mais especificamente à poesia que é posta em música, e avança no sentido de diferenciar a produção a que se refere daquela resultante do contraponto improvisado, limitando-se à produção escrita.

Em 1606, em seu tratado intitulado Poética Musical [Musica Poetica], Joachim Burmeister define seu objeto de estudo nos seguintes termos:

A poética musical, que Euclides chama de melopoeia, que seria o tratamento harmônico de um assunto, com a finalidade de adornar os argumentos de acordo com o que se trata, é aquela parte da música que ensina a compor o poema musical, unindo sons melódicos em harmonia, ornamentados com diversos afetos de períodos, a fim de mover as almas e os corações humanos ${ }^{6}$. (BURMEISTER, 1993, p. 16-17, tradução nossa)

\footnotetext{
${ }^{5}$ Differt a reliquis Musicae partibus. Theorica considerat, practica canit. Haec vero novas harmonias componit, et opus absolutum vel authore mortuo post se relinquit. Poetica musica duplex est, videlicet sortisatio et compositio. Sortisatio (ut ipsa appellatio indicat) est subita et impulsa supra cantum aliquem per diversas voces extemporalis pronuntiatio. Haec apud exteros [magis] usitatior est quam apud nos, et cum ex usu magis quam praeceptis pendeat [et oriatur ex compositione] minimeque vitiis careat [omissa hac ad compositionem accedamus] nam scripto comprehendere et studiosis tradere non est usitatum.

${ }^{6}$ Musica Poetica, quam Euclides melopoeia nominat, definitque esse usum harmonicae tractationi subectorum, ad decorum propositi argumenti, est illa musicae pars, quae carmen musicum docet conscribere, coniungendo sonos melodiarum in harmoniam, variis periodorum affectionibus exornatam, ad animos hominum cordaque in varios motus flectenda.
} 
Nessa definição, Burmeister dá um passo adiante em relação a seus antecessores, associando a poética musical ao conceito grego de melopoeia que, segundo Pereira (2001, p. 18), define a relação entre poesia e música, assumindo a origem da segunda na primeira, na medida em que a música "não preexiste independentemente da palavra, mas antes radica nela, inspira-se e brota a partir dela, constituindo ambas [música e poesia] um todo designado por melopoeia - composição melódica”. Nessa combinação, a forma de uso da linguagem verbal condiciona a forma de uso da música, pelo princípio do decoro, conforme se adornam "os argumentos de acordo com o que se trata" (BURMEISTER, 1993, p. 16). Nesses termos, podemos considerar que a palavra aplicada em sentido próprio, em textos simples, de cunho didático, por exemplo, comportaria música igualmente simples, ao passo que à palavra aplicada em sentido figurado equivaleria uma música proporcionalmente figurada, desviada do uso simples e comum. Essas medidas de uso da linguagem, que determinam seu grau de simplicidade e figuração, assim como os modos em que esses graus são representados, seja por meio de palavras e/ou sons musicais, são convençôes que qualificam as aparências de verdade consideradas válidas no contexto histórico-cultural em que se realizam. É nesse sentido que Burmeister faz referência à junção de “sons melódicos em harmonia”, circunscrevendo seu discurso à produção da música polifônica, textura própria do estilo vigente, que se caracteriza pela combinação de várias melodias simultâneas, que soem de maneira harmoniosa, conforme às regras do contraponto. Igualmente, podemos tomar a ornamentação da música com diversos afetos de períodos, algo que não aparece nas definições anteriormente citadas, e que pode ser entendido aqui como os desvios da forma mais simples de expressão, empregadas conforme processo analógico próprio que relaciona o gesto sonoro ao seu efeito no ouvinte, como forma de potencializá-lo no âmbito da apresentação de uma ideia completa, ou seja, no âmbito de um periodus. Esses afetos se materializariam no discurso musical na forma de figuras de expressão, ou seja, formas particulares de representação de ideias que, nas palavras de Burmeister, "se distanciam da razão composicional simples para assumir e vestir, com virtude, um caráter de ornamento." Nesse sentido, os afetos de períodos seriam as figuras empregadas pelos compositores para representar o sentido do texto nessas unidades gramático-retórico-musicais, os períodos.

Enfim, resta tratar da causa final da produção musical, que é definida por Burmeister como o movimento das almas e dos corações humanos. Sabemos, pelas artes retóricas, que esse movimento 
resulta da persuasão para as causas que o orador tem por tarefa defender. Neste caso, no exercício de seu ofício poético, o músico-orador luterano atuaria como instrumento das instituiçóes que o empregam - a Corte e a Igreja - com a finalidade de promover a missão delas em seus respectivos espaços de atuação: a primeira, de natureza temporal, civil e secular, e a segunda, de natureza atemporal, espiritual e religiosa (LUTERO, 2017a, pp. 5-7). Assim, a causa final da ação de produzir música, para além da obra produzida, conforme proposto por Listenius e Dressler, reside na função sócio-político-religiosa que ela desempenha no contexto cultural em que está inserida. Nesse contexto, a ação poético-musical cumpriria seu fim último e cobraria seu sentido na medida em que os movimentos da alma e do coração orientassem ações virtuosas e a elevação da alma, constituídas em hábitos por sua repetição e frequência (cf. Aristóteles, 2005, pp. 74, 77, 79, 107, 308, 309). Esses hábitos, por sua vez, contribuem para a edificação moral do indivíduo conforme às determinações religiosas e para a manutenção da ordem social que, na concepção luterana, é também de origem religiosa.

Conforme Rivera (In: BURMEISTER, 1993, p. 51), o tratado Musica Poetica foi escrito com a função de transmitir a músicos e compositores aspirantes uma doutrina amplamente aceita. Burmeister, na dedicatória de seu tratado, especifica suas intenções nos seguintes termos:

A fé me move a tratar do tema [a poética musical] apresentando preceitos, puxando minha orelha e me lembrando de que nenhuma arte liberal pode ser transmitida a alguém sem regras. Ela [a fé] me move a me abrir e a fazer crer que com ou sem a ajuda da natureza, imitação e prática, qualquer um pode elaborar uma compreensão da arte, uma vez que esteja amparado por um compêndio. De outra forma, natureza, imitação e prática, desacompanhadas dos textos instrucionais, não são capazes de conduzir ao domínio daquelas coisas que pertencem à arte, e nem a mestria será alcançada na falta de regras que eu considero essenciais a todo compêndio. A menos que sejam formuladas regras precisas, a arte para a qual a instrução é elaborada não será minimamente produzida, e assim ninguém alcançará um perfeito domínio dela. [...] A fim de resgatar a música desse destino [o desprezo decorrente de sua prática desregrada e descompromissada] tanto quanto eu puder - pois após longa consideração e atenção aos pedidos de Deus, eu compreendi que essa arte pode ser mais amplamente comunicada - eu não hesitei em escrever esses preceitos com a ajuda Dele e em organizá-los numa ordem precisa para o benefício de minha audiência. [...] Espero que vocês [cônsules e senadores do Governo de Rostock, patrocinadores da publicação] aceitem esse testemunho de minha intenção e determinação em ajudar zelosamente no aprimoramento do estudo e da prática da música, seja na escola ou na igreja, ou em qualquer outro lugar e tempo possível, assim 
como durante muitos anos eu cumpri minhas responsabilidades como mestre de capela ${ }^{7}$. (BURMEISTER, 1993, p. 4-7, tradução nossa)

Justificando seu trabalho como resultado do exercício da fé, Burmeister enfatiza a importância da sistematização do conhecimento para sua transmissão, especialmente na forma dos tratados, como o Musica Poetica. Relaciona esse conhecimento à natureza, ou seja, à inclinação natural do compositor para o exercício da técnica produtiva e à própria técnica, porquanto ela seja conhecimento e atividade especificamente humanos e, portanto, próprios da natureza humana. Relaciona esse conhecimento também à imitação das formas autorizadas e válidas de se produzir, na perspectiva de se reafirmar o costume e a ordem consolidadas pelas instituições vigentes e o valor das próprias instituiçôes; e finalmente relaciona-o à prática, ao fazer e refazer refletido, cotidianamente pensado, que conduz ao domínio da técnica. Burmeister afirma que esse conhecimento sistematizado resulta de longa consideração sua e ajuda divina. A longa consideração fica evidente na trajetória de suas publicações, que registram a formulação e reformulação de suas ideias ao longo do tempo e deixam claro a dedicação do autor ao seu objeto de estudos. A afirmação da ajuda divina reconhece, nos mesmos termos do poder secular, guardadas as devidas proporções, a participação de Deus na vida dos homens, garantindo a cada um, pela luz da Graça, as condiçóes para o cumprimento da função social que lhe compete. Por outro lado, se essa afirmação é tomada como artifício discursivo, constatamos que sua declaração outorga valor às regras formuladas, uma vez que elas resultariam de um extenso exame e estudo qualificados pela ajuda divina. Essa qualificação, por sua vez, situa o autor e seu texto, por extensão, entre o elenco daqueles a quem a autoridade é

\footnotetext{
${ }^{7}$ [arte hâc Musicâ ejusdemque tertiâ parte, Poeticâ dictâ, denuò mihi privatim explicanda veniente,] fides, quae in ijs requiritur, qui Artem in manus sumunt explanandam, me concitavit, ut praeceptis id certis praestarem, aures meas vellens et admonens nullam Artem Liberalem sine praeceptis tradi posse ulli, ut ut naturâ quemque imitatione et exercitiô, vel si non, compendiô tamen ipsam arripere posse mihi persuaderi paterer. Dum ne natura, imitatio, et exercitatio ad fastigia rerum, quae in Arte tractantur, sine artificij documentis contendere possint; imo ne id, in quo compendij illius rationem consistere arbitrer, praeceptionibus careat, imo etjam, quod in arte minimum est, de quo institutio suscipitur, nisi formatio ex certis de eo praeceptis sumatur, non percipi, ita nec artis praesidia quisquam habere possit perfecta. [...] A quo, quoad fieri, et quoad à me aliquid opis huc accedere potest, ut vindicetur, haec praecepta, quantum Deo suggerente jam longâ observatione notavi posse hanc Artem plenius communicari, eôdem coöperante conscribere, et in accuratioris ordinis formam redigere, ac ad Auditorum meorum placitum edere non detrectavi, cum ut ea ipsis fide debità constaret tradita esse, tum etjam ut eadem testarentur, quod, humilime de me sentiens nullôque invidiae oestrô percitus bonum publicum pro virili juvare, et qui ubetiora et meliora praestare possit, eum exemplô meô incitare vellem. Pariamini quoque idem animi mei et voluntatis esse testificationem musicum studium et exercitium sive in Schola, sive in Templo, sive quocunque in loco et quando possit, ut ut jam multos annos Cantoris munus deposuerim, prompte juvandi.
} 
outorgada, por analogia ao poder secular, para determinar o que se autoriza ou não fazer sobre determinada questão, neste caso, de natureza musical. Nesse sentido, a publicação de seu tratado, porquanto autorizada e financiada pelo Estado, constitui-se como instrumento definidor das práticas autorizadas, alinhadas à tradição instituída. Finalmente, Burmeister reitera sua intenção em contribuir para o aprimoramento do estudo e da prática da música, situando essas atividades na escola e na igreja, relacionando-os especificamente à educação de acordo com o currículo da escola latina [Lateinschule] e ao exercício religioso de acordo com as práticas e dogmas da igreja luterana.

Nesses termos, podemos considerar o exercício do ofício musical no contexto luterano também como um exercício político, na medida em que os compositores e executantes, cientes de sua função e valor social, a executavam como forma de contribuir para a manutenção da ordem social - que lhe garantia a manutenção de seu posto de trabalho e condição de subsistência - e a construção do bem comum. Além disso, podemos considerá-lo como um exercício de fé, assumindo essa função como desígnio divino, decorrente da vocação pessoal, de um chamado divino para a atuação no mundo. O exercício dessa função social, para além do compor e executar, implicava também, por um lado, no tornar o composto e executado inteligíveis para o público e, por outro lado, no tornar o composto e executado acessíveis às futuras geraçóes de compositores e executantes, a fim de que tivessem material para imitação e pudessem, por sua vez, eles também contribuírem para a manutenção das atividades constituídas como e pela tradição.

\section{REFERÊNCIAS}

ARISTÓTELES. Ética a Nicômaco. Madrid: Alianza Editorial, 2005.

BARBOSA, Luciane Muniz Ribeiro. Estado e Educação em Martinho Lutero: a origem do direito à educação. Cadernos de Pesquisa, São Paulo, v. 41, n. 144, p. 866-885, Dec. 2011. Disponível em: $<$ http://www.scielo.br/scielo.php?script=sci_arttext\&pid=S0100-

15742011000300012\&lng=en\&nrm=iso >. Acesso em: 10 Abr. 2020.

BARTEL, Dietrich. Musica Poetica - musical-rhetorical figures in German Baroque Music. Lincoln and London: University of Nebraska Press, 1997.

BOURDIEU, Pierre. Opoder simbólico. Lisboa: Difel, 1989.

BOURDIEU, Pierre. As regras da arte: gênese e estrutura do campo literário. São Paulo: Companhia das Letras, 2000.

BOURDIEU, Pierre. Questôes de Sociologia. Lisboa: Fim de Século, 2003. 
BURMEISTER, Joachim. Musical Poetics. New Haven \& London. Yale University Press, 1993.

BUTT, John. Music Education and the Art of Performance in the German Baroque. Cambridge: Cambridge University Press, 1994.

CAMBI, Franco. História da Pedagogia. São Paulo: Fundação Editora da Unesp, 1999.

DRESSLER, Gallus. Praecepta Musicae Poeticae. Anotações não publicadas de 1563. Disponível em: <http://www.chmtl.indiana.edu/tml/16th/DREPRA_TEXT.html>. Acesso em: 10 Abr. 2020 .

FABER, Heinrich. Ad musicam practicam introductio, non modo praecepta, sed exempla quoque ad usum puerorum accomodata, quàm breuissime continens. Nuremberg: In Officina Johannis Montani et Ulrici Neuber, 1550. Disponível em: <http://www.chmtl.indiana.edu/tml/16th/FABMUS1>. Acesso em: 14 Abr. 2020.

HANSEN, João Adolfo. Agudezas Seiscentistas e outros Ensaios. São Paulo: Editora da Universidade de São Paulo, 2019.

LISTENIUS, Nicolaus. Musica Nicolai Listenii ab authore denuo recognita multisque novis regulis et exemplis adaucta. Nuremberg: Petreius, 1549. Disponível em: <http://www.chmtl.indiana.edu/tml/16th/LISMUS>. Acesso em: 03 Mar. 2020.

LUCAS, Mônica. Emulação de retóricas clássicas em preceptivas da musica poetica. Opus, Porto Alegre, v. 20, n. 1, p. 71-94, jun. 2014.

LUTERO, Martim. Da autoridade secular. São Leopoldo/RS: Sinodal, 2017a.

LUTERO, Martinho. À nobreza cristã da nação alemã acerca da reforma do estamento cristão. In: LUTERO, Martinho. Martinho Lutero: uma coletânea de escritos. São Paulo: Vida Nova, 2017b. pp. 79-92.

LUTERO. Martinho. Aos Conselhos de Todas as Cidades da Alemanha para que criem e mantenham escolas cristãs. In: LUTERO, Martinho. Obras selecionadas - volume 5. São Leopoldo: Editora Sinodal, 1995. pp. 302-325.

LUTERO, Martinho. Preface to Georg Rhau's Symphoniae Iucundae. In: LEHMANN, Helmut. Luther's Works - volume 53 - Liturgy and Hymns. Philadelphia: Fortress Press, 1979.

LUTERO, Martinho. Prefácio ao Hinário Wittenberguense de 1524. In: LUTERO, Martinho. Obras Selecionadas - volume 7 - vida em comunidade. São Leopoldo/RS: Editora Sinodal, 2016a. pp. 480-481.

LUTERO, Martinho. Prefácio ao Hinário de Babst de 1545. In: LUTERO, Martinho. Obras Selecionadas - volume 7 - vida em comunidade. São Leopoldo/RS: Editora Sinodal, 2016b. pp. 481-482.

LUTERO, Martinho. Prefácio a todos os bons hinários. In: LUTERO, Martinho. Obras Selecionadas - volume 7 - vida em comunidade. São Leopoldo/RS: Editora Sinodal, 2016c. pp. 483-484.

MANACORDA, Mario A. História da Educação - da antiguidade aos nossos dias. São Paulo: Cortez, 2010. 
PEREIRA, Aires Manuel R. dos Reis. A Mousiké: das origens ao drama de Euripedes. Lisboa: Fundação Calouste Gulbenkian, 2001.

SKINNER, Quentin. The foundation of modern political thought - volume II: the age of reformation. Cambridge: Cambridge University Press, 2004.

SKINNER, Quentin. As fundaçôes do pensamento politico moderno. São Paulo: Companhia das Letras. 1996.

VLASTUIN, Willem van. Sola Scriptura: The Relevance of Luther's Use of Sola Scriptura in De Servo Arbitrio. In: BURGER, Hans; HUIJGEN, Arnold et al (Ed.). Sola Scriptura - Biblical and Theological Perspectives on Scripture, Authority, and Hermeneutics. Boston, Leiden: Brill, 2018. pp. 243-259.

\section{SOBRE O AUTOR}

Cassiano Barros é bacharel (2001 - Música - Regência e Cravo), mestre (2006) e doutor (2011) em Música pela Universidade Estadual de Campinas - Unicamp. Tem experiência na docência no ensino superior, na formação de músicos e professores de música. Dedica-se principalmente ao ensino e à pesquisa, com ênfase nas áreas da Musicologia, História da Teoria Musical (poéticas antigas e retórica musical), Regência e Educação Musical. Atualmente, desenvolve projeto de pós-doutorado no Programa de Pós-Graduação em Música da Universidade do Estado de Santa Catarina Udesc com apoio da Capes. É autor do livro Uma chave para a música do século XVIII, publicado pela Editora Appris em 2019. ORCID: https://orcid.org/0000-0002-2687-7201. E-mail: cassianobarros@hotmail.com. 